\title{
POLQ Gene
}

National Cancer Institute

\section{Source}

National Cancer Institute. POLQ Gene. NCI Thesaurus. Code C131801.

This gene is involved in DNA synthesis and repair. 